\title{
A Review on Effect of Building Integrated Photovoltaic Placement and its Potency in Generating Electrical Energy
}

\author{
B. Rudianto ${ }^{1}$, S.N.N. Ekasiwi², I.G.N. Antaryama ${ }^{2}$
}

\begin{abstract}
BIPV is an integral part of the building envelope such as the roof or the facade. There is a difference of Building Integrated Photovoltaic placement between the location in the equator region and other regions. The study aims to know the effect of BIPV placement and its potency in generating electrical energy. The study reviews previous research related topics of $B I P V$ in all regions. The study shows that BIPV placement is determined by the sun's position that producers incidence angle. Incidence angle should fall perpendicularly on a surface to obtain the high of an intensity of solar irradiation. Therefore, most of BIPV placement in the equator region are on rooftops while in the regions far from equator not only on rooftops but also on facades. Roofs are so far considered to be the ideal location for BIPV placement since roofs provide the best solar energy generation. The potency of BIPV can be explored in building design with the variation of orientation and shape to increase the building surfaces for getting solar potential.
\end{abstract}

Keywords-BIPV Placement, Energy Generation, Incidence Angle, Orientation, Tilt Angle.

\section{INTRODUCTION ${ }^{1}$}

Sunlight is a renewable energy source that available abundantly on earth and sustainable. Sunlight has been used in buildings for the purpose of daylighting and heating. With technological development, sunlight is utilized to generate electrical energy through solar collector technology. The challenge of building design currently is not only able to overcome the climate condition but also contribute to sustainable context. BIPV is a photovoltaics integration into the building envelope. BIPV follows the orientation and tilt angle where its placement as a roofs or facades. The dynamic sun position throughout the year makes the difference BIPV placement on each latitude. The study aims to know the effect of BIPV placement and its potency in generating electrical energy in equator region and region far from the equator.

\footnotetext{
${ }^{1}$ B. Rudianto is with Ph.D Program, Department of Architecture, Faculty of Civil Engineering and Planning, Institut Teknologi Sepuluh Nopember (ITS), Kampus ITS Sukolilo, Surabaya 60111, Indonesia. Email: brudianto7@gmail.com.

${ }^{2}$ S.N.N. Ekasiwi, I.G.N. Antaryama are with Department of Architecture, Faculty of Civil Engineering and Planning, Institut Teknologi Sepuluh Nopember (ITS), Kampus ITS Sukolilo, Surabaya 60111, Indonesia. E-mail: nastiti@arch.its.ac.id; antaryama@arch.its.ac.id.
}

\section{LITERATURE REVIEW}

\section{A. Solar Geometry and Solar Radiation}

The positions of the sun against the earth are defined with the angles i.e. i) solar altitude angle ( $\alpha$ s), the vertical angle between the sun's position and the earth horizontal plane, ii) solar azimuth angle $(\gamma s)$, the horizontal angle between the sun's position and the Northern/Southern axis of the earth, iii) zenith angle $(\theta z)$, the vertical angle between normal surface of the earth (zenith) minus solar altitude angle. The positions of the PV panel is defined with slope angle $(\beta)$, the vertical angle between the panel surface to incidence angle and the earth horizontal plane. See Figure 1 (left).

The distance between the sun and the earth at one astronomical unit $\left(1.495 \times 10^{11} \mathrm{~m}\right)$ is called the solar constant with a value of $1,367 \mathrm{~W} / \mathrm{m}^{2}$. The value of the solar radiation decreases as it passes through the atmosphere by about $50 \%$. The principle of the angle of sunlight coming parallel to the earth causes the equator region to receive the incidence angle relatively perpendicular. Lambert cosine law states that the value of the intensity of light on a surface is directly proportional to the intensity of the light falling perpendicularly multiplied by the cosine of the incidence angle of light on a surface [1]. See figure 1 (right). The Lambert cosine law shows that the acquisition of energy from solar radiation is highly dependent on the angle of coming from direct sunlight. Therefore, incidence angle is very decisive for solar energy calculation.
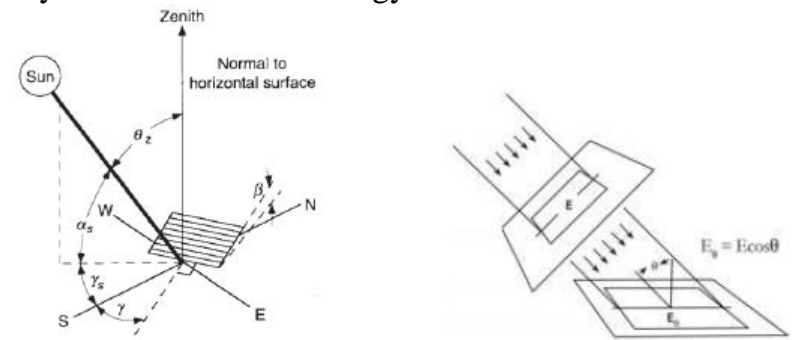

Figure 1. Solar Geometry [2] and Schematic of Lambert Cosine Law [1]

\section{B. Solar Panel System}

Photovoltaics (PV) is a method to produce electrical energy by converting solar radiation into DC electric current energy through the use of semiconductor technology and photovoltaic effects [3]. Factors affecting the performance of solar panels are the technology/type of photovoltaic and local conditions that include latitude, sun exposure value, outdoor air temperature, and environment 
[4]. Optimum orientation and tilt angle to obtain a high intensity of sunlight to produce maximum electrical energy on solar panel system with provisions i.e. the orientation facing perpendicular to the equator and the tilt angle is the same as the latitude value [2].

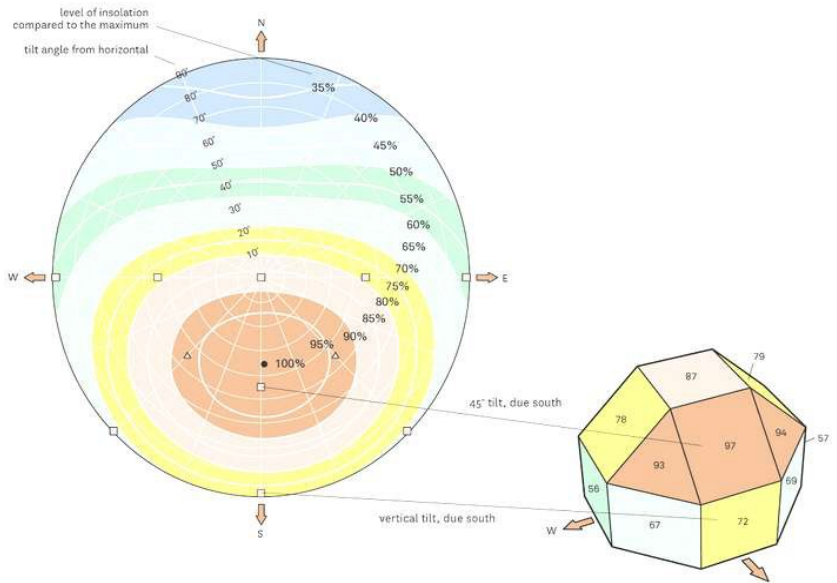

Figure 2. The Relationship of Insolation and Orientation and Slope Angle for Latitude $30^{\circ} \mathrm{N}$ [5]

Figure 2 shows the value of insolation as the function of orientation and slope angle for latitude $30^{\circ} \mathrm{N}$. Red color describe the value of insolation more than $90 \%$ of the maximum insolation (perpendicular to equator). The value of insolation will decrease if the orientation is not perpendicular to equator and the slope angle is smaller or bigger than $30^{\circ}$ (Note: the value of insolation of pink: $\geq$ $80 \%$, yellow: $\geq 70 \%$, and bright blue: $\geq 60 \%$ ).

\section{Building Integrated Photovoltaic}

BIPV is an integration of photovoltaic materials that replace the building envelope's materials as a roof or facade element so that architecturally more united with the design of the building. BIPV has a function not only as a building envelope but also as a harvester of solar energy [6]. The building envelope provides several options for laying down photovoltaic materials i.e. on flat roofs, sloped roofs, facades, and shading systems (see figure 4). On the sloped roofs, the performance of photovoltaic is determined by orientation, tilt angle, and available surface. On the flat roofs, irrespective of the orientation. On the facades and sun shading give improve the appearance of the building better.

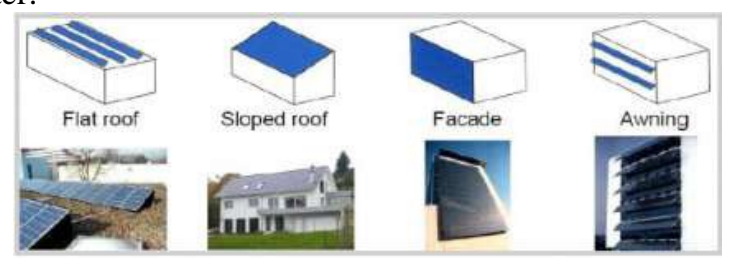

Figure 4. Typology of BIPV on the Building [7].

BIPV products offer color variations, transparencies, shapes, and sizes as well as multiple functions. Various BIPV products include: modules, tiles/shingles, foils, and glazing. BIPV tiles/shingles are applied to the roof with a material the size of the existing material. BIPV foils is applied to the curved surface of the roof. BIPV glazing is applied to transparent roof/facades/windows [8]. The advantages of BIPV are the combination of multiple functions, saving building materials, architecturally more attractive, requiring no land for installation, requiring no separate support structures, reducing construction and maintenance costs [9]. Disadvantages of BIPV are more difficult handling in maintenance and component displacement [6].

\section{BIPV in Building Design}

Knowles [10] introduced the concept of solar envelope in obtaining access to sunlight for the purpose daylighting and heating. Solar envelope is the maximum limit of building volume that does not haunt the surrounding environment for a certain period. Solar envelope produces a pyramidal shape that is formed from the intersection of the incident angle of direct sunlight that is the daily period and the annual period. The daily period cuts the field in the morning and in the afternoon. The annual period cuts the current field of winter and summer. The ability to expand the surface of the building to gain access to sunlight is used by BIPV in acquiring expansive areas of sunlight.

Figure 3 below shows the solar envelope with orientation of East- West direction has the largest volume and highest roof ridge than other orientations. Solar envelope with EastWest orientation is the best for solar panel utilization by producing $40 \%$ larger volume and $400 \%$ larger surface of roof facing to equator.

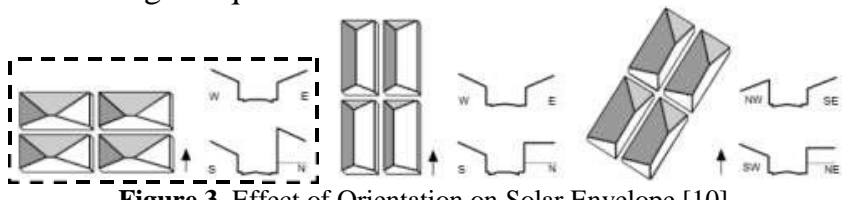
Figure 3. Effect of Orientation on Solar Envelope [10].

\section{METHODS}

The study reviews previous research related topics of BIPV. The selected study that meets criteria then identified and grouped based on the latitude location. The area of selected study includes Malaysia, Singapore, Brazil, Australia, Greece, Korea, and Canada.

The area of study is classified in two groups of latitude locations i.e.: i) application of BIPV in the equator region, ii) application of BIPV in regions far from the equator. Discussions observe the effect of BIPV placement and its potency at each group of latitude location.

\section{RESULTS AND DISCUSSION}

\section{A. Application of BIPV in The Equator}

Othman \& Rushdi [7] investigated the performance of BIPV application and the roof form that can improve the performance on urban housing in Shah Alam, Malaysia. They used secondary data was gathered through related literature review as a guideline for conducting research. Few houses with BIPV installations in location were identified and observed. Two types of PV technology i.e. mono- crystalline and poly-crystalline have been measured. The level of solar intensity was recorded within a space of 2 hours (from 11.00 AM to 1.00 PM). Two samples of object study with difference BIPV application on the difference the roof form are shown in figure 5 . 


\begin{tabular}{|c|c|c|c|c|c|c|c|}
\hline Sample & $\begin{array}{c}\text { Image and PV } \\
\text { Application Type }\end{array}$ & pV Type & $\begin{array}{l}\text { PV } \\
\text { Surface } \\
\text { Area }\end{array}$ & $\begin{array}{c}\text { Direct } \\
\text { Sun } \\
\text { Expos } \\
\text { ure } \\
\text { Hours }\end{array}$ & $\begin{array}{l}\text { Energy } \\
\text { Generated }\end{array}$ & $\begin{array}{l}\text { Roof } \\
\text { Type } \\
\text { and } \\
\text { slope }\end{array}$ & Orientation \\
\hline $\begin{array}{l}\text { Bandar } \\
\text { Eco } \\
\text { Setia, } \\
\text { Phase 2 }\end{array}$ & $\underset{\substack{1 \\
\text { Retrofitted }}}{ }$ & $\begin{array}{c}5.28 \mathrm{kWp} \\
\text { Mono- } \\
\text { Crystalline, } \\
\text { Suntech } \\
\text { STP } 175 \mathrm{~s}\end{array}$ & $\begin{array}{c}1100 \mathrm{x} \\
1300 \mathrm{~mm} \\
\mathrm{x} 30 \mathrm{nos} \\
=42 . \\
\mathrm{m}^{2}\end{array}$ & $\begin{array}{l}8-12 \\
\text { hours }\end{array}$ & $\begin{array}{l}29.172 \\
\text { kWh per } \\
\text { day } \\
\text { exposure }\end{array}$ & $\begin{array}{c}\text { Pitch } \\
\text { roof } @ \\
15^{\circ}\end{array}$ & $\begin{array}{l}\text { Roof } \\
\text { surface } \\
\text { facing } \\
\text { north and } \\
\text { south }\end{array}$ \\
\hline $\begin{array}{l}\text { Setia Eco } \\
\text { Park, } \\
\text { Columba }\end{array}$ & 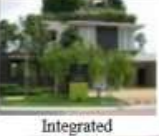 & $\begin{array}{l}5.28 \mathrm{kWp} \\
\text { Mono- } \\
\text { crystalline, } \\
\text { Solarworld } \\
165\end{array}$ & $\begin{array}{c}1318 \mathrm{x} \\
994 \mathrm{~mm} \\
\times 32 \mathrm{nos} \\
=41.9 \\
\mathrm{~m}^{2}\end{array}$ & $\begin{array}{l}8-12 \\
\text { hours }\end{array}$ & $\begin{array}{l}28.5 \mathrm{kWh} \\
\text { per day } \\
\text { exposure }\end{array}$ & $\begin{array}{l}\text { RC Flat } \\
\text { roof }\end{array}$ & $\begin{array}{l}\text { Roof } \\
\text { surface } \\
\text { facing the } \\
\text { sky }\end{array}$ \\
\hline
\end{tabular}

Setia Eco Park with a number 1100 x $1300 \mathrm{~mm}$ size of mono- crystalline panels able to generate 10,650 kWh annually and Setia Eco Villas with a number of 1318 x 994 mm size of mono-crystalline panels able to generate 10,400 $\mathrm{kWh}$ per year. The differences in producing electrical energy of two BIPV applications that has same PV technology are due to the difference of total surface areas, tilt angle, and orientation. Roof with low slopes and flat roof able to reach sun exposure hours experienced about 810 hours, irrespective of the orientation. While roof with a slope greater than $20^{\circ}$, orientations able to influence the sun exposure hours of surface areas due to some part of the surface shaded by its own roof structure.

The study of Othman \& Rushdi [7] shows that the pitched roof with a slope lower than $20^{\circ}$ facing any orientation can have a longer sun exposure hour so that able to produce more electrical energy. The geometry of roof shape has an influence on the surface area that determines the number of PV modules that can be installed such as a hip roof.

A comprehensive study conducted in the Southern hemisphere by Cronemberger [11] that observed the availability of solar potential yield in 78 Brazilian cities located between latitude $0^{\circ}$ and $30^{\circ} \mathrm{S}\left(0^{\circ} \leq \varnothing \leq 30^{\circ} \mathrm{S}\right)$ to evaluate the suitability of the buildings' envelopes for photovoltaic. They identified optimal tilt angle of fixed surfaces in 78 Brazilian cities using secondary data that published by the World Radiation Data Center. Then, investigated the amount of solar irradiation in detail on 7 cities representation of wide latitude range. The optimal tilt angle is defined as the tilt angle of a fixed surface, measured from the horizontal plane, which receives the maximum annual amount of solar irradiation.

It was found, only 8 cities that have the optimal tilt angle is equal to the latitude. While other 70 cities, the optimal tilt angle is higher than latitude with varies between $1.5^{\circ}$ and $9.3^{\circ}$.

In the 7 cities $\left(0^{\circ} \leq \varnothing \leq 30^{\circ} \mathrm{S}\right)$, the available solar irradiation on roofs $\left(\beta=0^{\circ}-30^{\circ}\right)$ facing North is always more than $89 \%$ of the maximum irradiation for an optimally-inclined-oriented surface. In the cities $\left(1^{\circ} \leq \varnothing \leq\right.$ $10^{\circ} \mathrm{S}$ ), the available solar irradiation on roofs facing East/West is more than $93 \%$, while in the cities $\left(15^{\circ} \leq \varnothing \leq\right.$ $30^{\circ} \mathrm{S}$ ) between $85 \%-89 \%$. In the cities $\left(1^{\circ} \leq \varnothing \leq 10^{\circ} \mathrm{S}\right)$, the available solar irradiation on roofs facing South is more than $83 \%$, while in the cities $\left(15^{\circ} \leq \varnothing \leq 30^{\circ}\right.$ S) between $66 \%-71 \%$. The best results of the available solar irradiation are on roof surface facing North for the cities $\left(1^{\circ} \leq \varnothing \leq\right.$ $\left.10^{\circ} \mathrm{S}\right)$ followed by facing North for the cities $\left(15^{\circ} \leq \varnothing \leq 30^{\circ}\right.$ $\mathrm{S})$, facing East/West for the cities $\left(1^{\circ} \leq \varnothing \leq 10^{\circ} \mathrm{S}\right)$, facing
East/West for the cities $\left(15^{\circ} \leq \varnothing \leq 30^{\circ} \mathrm{S}\right)$, facing South for the cities $\left(1^{\circ} \leq \varnothing \leq 10^{\circ} \mathrm{S}\right)$, facing South for the cities $\left(15^{\circ} \leq\right.$ $\left.\varnothing \leq 30^{\circ} \mathrm{S}\right)$.
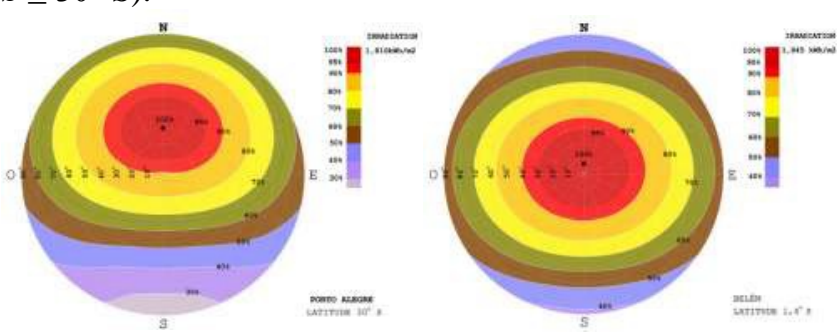

Figure 6. Annual global irradiation chart of Porto Alegre and Belem [11].

Figure 6 (left) shows the city of Porto Alegre $\left(\varnothing=30^{\circ} \mathrm{S}\right)$ has the maximum global irradiation with a surface inclined $30^{\circ}$ facing North. The optimal combination (red color: irradiation usage $\geq 90 \%$ ) is wide: tilts between $2^{\circ}$ and $58^{\circ}$, orientations from Northwest to Northeast.

Figure 6 (right) shows the city of Belem $\left(\varnothing=1.4^{\circ} \mathrm{S}\right)$ has the maximum global irradiation with a surface inclined $7^{\circ}$ facing North. The optimal combination of orientation and tilt angle are facing any orientation and tilt angles up to $40^{\circ}$. The range of optimal combination is now in the center of the chart.

The available solar irradiation on facades $\left(\beta=40^{\circ}-90^{\circ}\right)$ is less than on roofs, below $60 \%$. In the 7 cities $\left(15^{\circ} \leq \varnothing \leq 30^{\circ}\right.$ $\mathrm{S})$, the available solar irradiation on facades facing North is between $55 \%-60.3 \%$, while in the cities $\left(1^{\circ} \leq \varnothing \leq 10^{\circ} \mathrm{S}\right)$ between $42 \%-45.6 \%$. In the cities $\left(15^{\circ} \leq \varnothing \leq 30^{\circ} \mathrm{S}\right)$, the available solar irradiation on facades facing East/West is between $54.5 \%-55.3 \%$, while in the cities $\left(1^{\circ} \leq \varnothing \leq 10^{\circ} \mathrm{S}\right)$ between $54.6 \%-56.4 \%$. In the cities $\left(15^{\circ} \leq \varnothing \leq 30^{\circ} \mathrm{S}\right)$, the available solar irradiation on roofs facing South is between $26 \%-28.6 \%$, while in the cities $\left(1^{\circ} \leq \varnothing \leq 10^{\circ} \mathrm{S}\right)$ between $32 \%-37.8 \%$. The best results of the available solar irradiation are on facade surface facing North for the cities $\left(15^{\circ} \leq \varnothing \leq 30^{\circ} \mathrm{S}\right)$ followed by facing East/West for the cities $\left(15^{\circ} \leq \varnothing \leq 30^{\circ} \mathrm{S}\right)$, facing East/West for the cities $\left(1^{\circ} \leq\right.$ $\left.\varnothing \leq 10^{\circ} \mathrm{S}\right)$, facing North for the cities $\left(1^{\circ} \leq \varnothing \leq 10^{\circ} \mathrm{S}\right)$, facing South for the cities $\left(1^{\circ} \leq \varnothing \leq 10^{\circ} \mathrm{S}\right)$ and facing South for the cities $\left(15^{\circ} \leq \varnothing \leq 30^{\circ} \mathrm{S}\right)$.

For the cities $\left(1^{\circ} \leq \varnothing \leq 10^{\circ} \mathrm{S}\right)$, the available solar irradiation on facades facing East/West is higher than facing North and South. In Belem ( $\left.\varnothing=1.4^{\circ} \mathrm{S}\right)$, the difference of the available solar irradiation between facing North and South is low. So it faces all orientation. These results are significant for the design of building envelope surfaces, which not only pat attention to the vertical ones but also inclined surface, like shading elements on facades and windows.

Brazil located in the width latitude range so it has extensive experience facing equator climate and beyond the equator. The result of identified, the tilt angle of the surface (78 cities) reaches more 9 degrees than the latitude value to gain maximum irradiation. It could be at the time of the sun's position is in the Northern hemisphere. With the width of the latitude range in Brazil, they divided the location of study in a range $\left(1^{\circ} \leq \varnothing \leq 10^{\circ} \mathrm{S}\right)$ for the equatorial region and in a range $\left(15^{\circ} \leq \varnothing \leq 30^{\circ} \mathrm{S}\right)$ for regions far from the equator. On roofs, the optimal solar irradiation located in the cities $\left(1^{\circ} \leq \varnothing \leq 30^{\circ} \mathrm{S}\right)$ facing 
North. On facades, the optimal solar irradiation located the cities $\left(15^{\circ} \leq \varnothing \leq 30^{\circ} \mathrm{S}\right)$ facing North and the cities $\left(1^{\circ} \leq \varnothing \leq\right.$ $\left.10^{\circ} \mathrm{S}\right)$ facing East/West.

The study of Cronemberger [11] shows that getting closer to the equator, the availability of solar potential yield on the roofs is facing North (Southern hemisphere). The farther from the equator, the availability of solar potential yield on the facades is facing North. According to Cronemberger [11], the equatorial region in this study is defined as an area with latitude range 10 degrees to North and to South from the equator line $\left(10^{\circ} \mathrm{N} \leq \varnothing \leq 10^{\circ} \mathrm{S}\right)$. City of Belem $(\varnothing=$ $1.4^{\circ} \mathrm{S}$ ) has the maximum global irradiation with a surface inclined $7^{\circ}$ facing North. Cronemberger [11] support the study of Othman \& Rushdi [7] that the roof should have a low slope to get the maximum global solar irradiation in any orientation.

While Saber [12] evaluated the energy yield prediction of BIPV system on Zero Energy Building (ZEB) in Singapore. They measured the performance of BIPV systems on ZEB existing, made the geometry model of $\mathrm{ZEB}$ in variation three types PV technology i.e. mono-crystalline, polycrystalline, and amorphous, then simulate with EnergyPlus program. The ZEB is a zero energy building that produces enough energy to run itself. The building is powered by a broad spectrum of the grid-tied and stand-alone system. Surplus power generated is distributed to the surrounding.

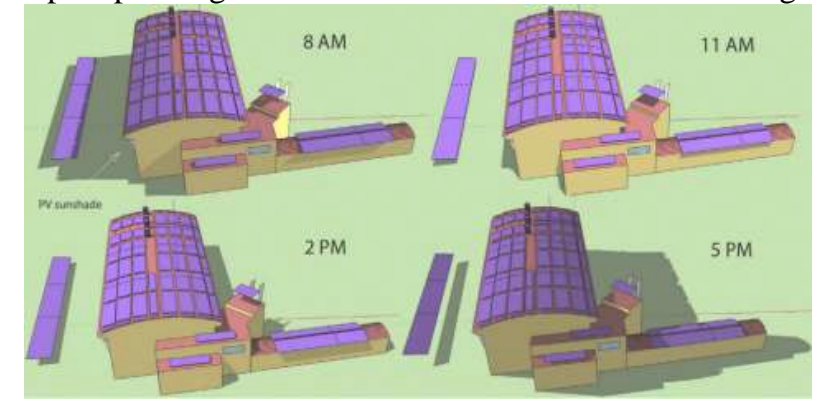

Figure 7. ZEB Model on $7^{\text {th }}$ of July under Clear Sky (8 AM to 5 PM)[12]

Figure 7 shows ZEB model in shadow zones at different times in a day. Predicting the shadow in a year is the important factor for estimating the annual energy yield.

From predicted annual energy yield on low-slope PV rooftop, poly- crystalline is the most energy production for this climate. The effect of orientation for low-slope $\left(15^{\circ}\right)$ modules is negligible. The East oriented modules produce slightly higher energy than North, South, and West oriented. From predicted annual energy yield on PV sunshade, poly-crystalline on east facades with slopes in a range of $30-45^{\circ}$ is the better places of energy production and inclination than slopes $60^{\circ}, 15^{\circ}$, and $0^{\circ}$.

The study of Saber [12] shows that increasing sloping angle of the PV rooftop causes the orientation has no effect on the production of energy yield. The East-West facades with slopes in a range of $30-45^{\circ}$ are the best places for external shading to gain solar radiation due to the low of incidence angle in the morning and afternoon.

The study of Saber [12] strengthens the study of Othman \& Rushdi [7] and Cronemberger [11] that slope angle should has a low slope to get the maximum global irradiation in any orientation. With the low curved roof shape, the shadow effect due to the time function has no significant effect on the roof surface.

\section{B. Application of BIPV in Regions Far from The Equator}

Yan [13] investigated the performance of BIPV system with the variation of tilt angles and orientations in Brisbane, Australia $\left(27.47^{\circ} \mathrm{S}\right)$. They measured the performance of BIPV rooftop on UQ Center building. The experiment used two PV array with difference of the amount and orientation i.e. 56 panels tilted $5.5^{\circ}$ to the North $\left(5.5^{\circ} \mathrm{N} / 56\right)$ and 60 panels tilted $2.5^{\circ}$ to the South $\left(2.5^{\circ} \mathrm{S} / 60\right)$. Then, to made the simulation using year long recorded data from the University of Queensland.

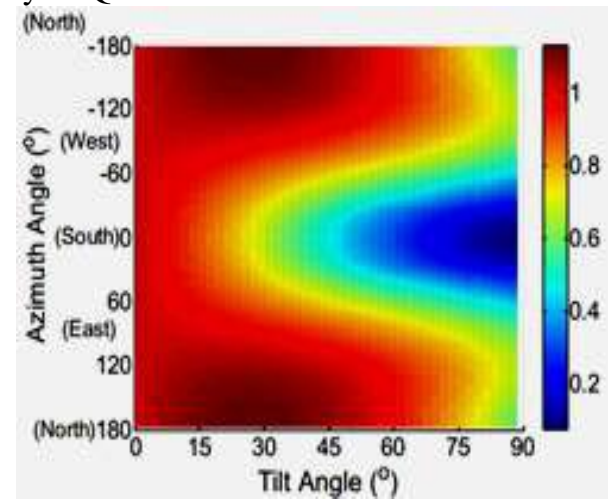

Figure 8. Energy Generation vs Tilt and Azimuth Angles Variation.[13]

Figure 8 shows the effect of tilt and azimuth variation to energy generation of PV array in Brisbane. The greater the energy production when with the angle of slope approaching latitude value and orientation facing North. The lesser the energy production when with the angle of the slope away from latitude and orientation toward the South. Therefore, the $5.5^{\circ} \mathrm{N} / 56$ system generates more energy than the $2.5^{\circ} \mathrm{S} / 60$ system. The theoretically optimal tilt angle and orientation for BIPV systems in Brisbane, Australia will be approximately $26^{\circ} \mathrm{N}$ facing true North (Southern Hemisphere). The study of Yan et al. (2013) shows that the BIPV systems with tilt angle $26^{\circ}$ facing North are the best energy production due to Australia located in the South, in Brisbane, Australia (27.47 $\mathrm{S}$ ). The optimal angle found slightly smaller than the latitude value shows the observations made when the sun's position in the Southern hemisphere.

Kaldellis \& Zafirakis [14] evaluated the performance of different PV panel tilt angles on a rooftop during the summer period in Athens, Greece $\left(37.97^{\circ} \mathrm{N}\right)$. The experimental measurements conducted on the roof of building laboratory of Piraeus Campus. Two pairs of PV array are used as case study i.e. a fixed angle PV array in $15^{\circ}$ and a variable angle PV array $\left(0^{\circ}, 15^{\circ}, 30^{\circ}, 45^{\circ}, 60^{\circ}\right.$, and $75^{\circ}$ ). Measurements together between a fixed angle and a variable angle were taken every 10 min during daylight at the hot period of the year (from mid-May to midSeptember). 


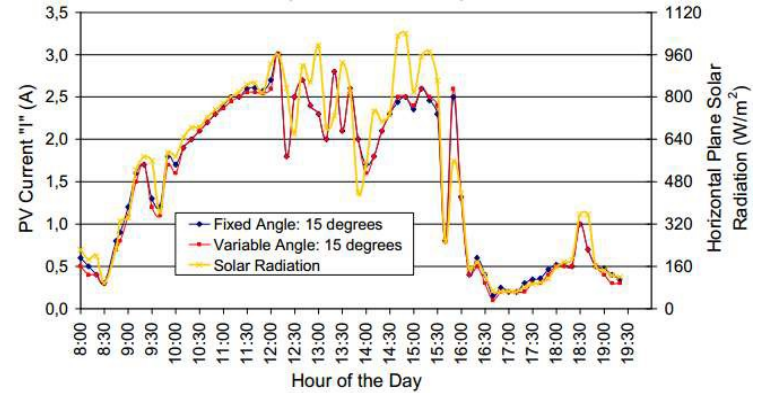

Figure 9. Current Production and Hourly Irradiance Variation[14]

Figure 9 shows the fixed angle $15^{\circ}$ and the variable angle $15^{\circ}$ has the similarity fluctuation of solar radiation and PV output in the summer period. The deviation of the PV pairs angle $15^{\circ}-15^{\circ}$ is more little than the deviation of PV pairs angle $15^{\circ}-0^{\circ}, 15^{\circ}-30^{\circ}, 15^{\circ}-45^{\circ}, 15^{\circ}-75^{\circ}$, and $15^{\circ}-60^{\circ}$. The angle of $15^{\circ}\left( \pm 2.5^{\circ}\right)$ is optimum tilt angle for the maximum energy production the entire summer season in Athens.

The study of Yan [13] shows that tilt angle must be reduced from the latitude value to get an incidence angle more perpendicular due to the high sun's position in summer in Athens-Greece $\left(37.97^{\circ} \mathrm{N}\right)$. Kaldellis \& Zafirakis [14] supports the study of Yan [13] but with a significant reduction difference to obtain an optimum slope angle to the latitude value.

Hwang [15] analyzed the energy production of BIPV systems on facades of high rise building in Incheon, Korea. They conducted simulation on the Samsung office buildings (Bldg. A and Bldg. B) with facade variations. They use variation of wall in orientation, horizontal/vertical inclined angle, and a density of positioning.

The maximum electric energy is produced during April and May, Energy production significantly decreases in July. This is due to weather conditions in Korea, such as the rainy season and the lower number of sunny days. The Southeast and Southwest PV modules have a high production throughout the year, and the Northeast and Northwest PV modules show significantly lower energy production in late autumn and winter.

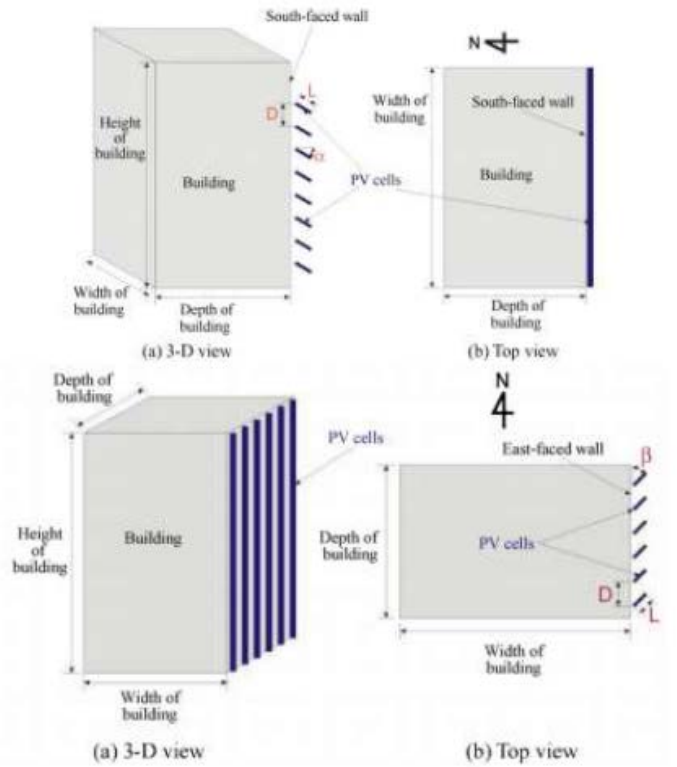

Figure 10. Installing arrangements of PV panels for the south-facing wall and east-facing wall[15].
Figure 10 shows the position of horizontally inclined angle $(\alpha)$ and a vertically inclined angle $(\beta)$. The distance between PV panel represent a density of positioning.

Building can harvest the maximum energy production on mono- crystalline PV panels with a horizontally inclined angle of $60^{\circ}$ and a vertically inclined angle that is smaller than $15^{\circ}$. The optimal solution for applying BIPV systems is a function of facade surface area, the inclination of panel, module type, installation distance to module length ratio, and direction.

The study of Hwang [15] shows that the inclination of horizontal panel is lower than inclination of vertical panel due to the wider of panels surface area exposed. The facades with orientation that is not perpendicular to the equator (North) i.e. Southeast and Southwest is able to gain high energy production. Kaldellis \& Zafirakis [14] and Yan [13] observed BIPV systems on typology of alow-rise building with application on roofs, while Hwang [15] observed BIPV systems on a typology of highrise building with an application on facades. The three studies on regions far from the equator show the variation in results due to dynamic movement of sun's position at each latitude location.

\section{The Potency of BIPV in Building Design}

Hachem [16] conducted the model study of the typical dwelling unit in expanding the building envelope surface for solar access that applies photovoltaic system on setting neighborhood urban informal settlement in Canada (latitude $\left.45^{\circ} \mathrm{N}\right)$.

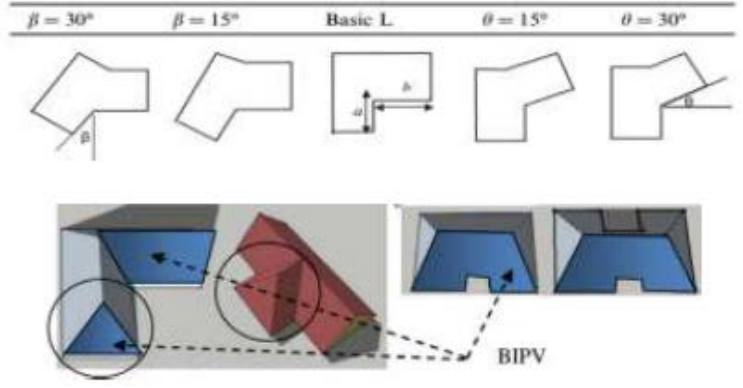

Figure 11a. Layout Type-L and Roof Type non-Convex (L, T, U, H)[16].

The strategy to increase the solar potential of typical dwelling unit with the variation of layout proportion (ratio $\mathrm{a} / \mathrm{b}$ ), the variation of wing angle $(\theta, \beta)$, and using combination roof (gable-hip) with a slope angle of $45^{\circ}$. While the strategy to increase the solar potential of the typical dwelling unit at site layout with the variation of orientation, street pattern and density.

On the detached configuration, the annual production of electrical energy the typical dwelling unit at site layout III is bigger than site layout II due to has the building envelope surface that is widely exposed. On the attached configuration, the annual production of electrical energy at site layout III and II are more than 50\% and 36\% than at site layout I (straight street pattern). The annual production of electrical energy at site layout III and II are more than $9 \%$ and $6 \%$ than at site layout I. Site layout variation with curved street pattern can be shown in figure 11b below. 


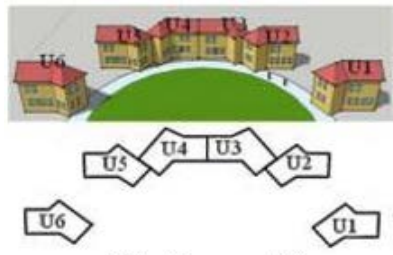

Site Layout II

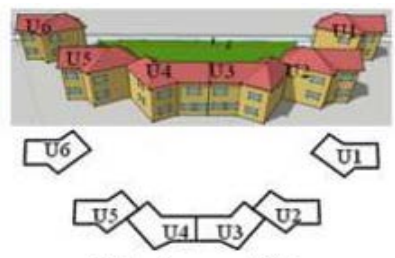

Site Layout III

Figure 11b. Site Layout Variation in Attached Configuration [16].

Site layout II and III able to produce electrical energy with the different time of peak generation spreadly almost 6 hours among unit configurations. This can be an economic advantage since the cost and price of electricity often vary according to the time of day. Figure 11c shows the more varied the orientation of the unit the more varied the peak generation distribution on the site layout.

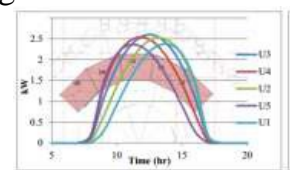

Figure 11c. Hourly Electricity Generation of Units on Site Layout Variation [16].

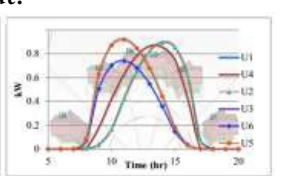

Her study proposed a residential unit design that could further maximize potential solar on the roof and facade surfaces by folding plates and split-surface. See Figure 11d. The calculation results show the annual energy production $(\mathrm{kWh} / \mathrm{yr})$ with folded plates is better than with splitsurfaces. For split-surface in configuration-1 (8,814 $\mathrm{kWh} / \mathrm{yr})$ and configuration-2 $(8,536 \mathrm{kWh} / \mathrm{yr})$. For folded plates in configuration-1 $(9,460 \mathrm{kWh} / \mathrm{yr})$ and configuration$2(9,743 \mathrm{kWh} / \mathrm{yr})$.
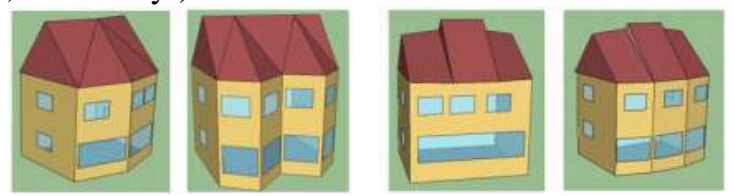

Figure 11d. Proposed Design Variation of Dwelling Unit [16].

It is said the results of her study show the design aspect can maximize potential solar, how to find the best configuration to avoid imagery, how to take advantage of road forms to strengthen the energy performance of a neighborhood.

The study of Hachem [16] shows the ability to expand the surface of the building in obtaining access to sunlight is utilized by BIPV system in acquiring expansive areas of sunlight. Solar envelope concept applied not only on a roof but also on facades. The variations of incidence angle cause the facades as an alternative of BIPV placement.

TABLE 1.

SUMMARY STUDIES.

\begin{tabular}{lcl}
\hline \hline Location & BIPV & \multicolumn{1}{c}{ Result } \\
\hline Malaysia & Roof & $\begin{array}{l}\text { BIPV application on roof with low slopes and } \\
\text { flat roof able to reach sun exposure hours } \\
\text { experienced about } 8-10 \text { hours, irrespective of } \\
\text { the orientation. Roof form has slope more than } \\
\end{array}$ \\
& & $\begin{array}{l}20^{\circ} \text { facing East-West, therefore, limiting the } \\
\text { solar exposure hour by half, hence less power } \\
\\
\end{array}$ \\
& generation [7].
\end{tabular}

Brazil

Roof The tilt angle of the surface (78 cities) reaches and more 9 degrees than the latitude value to gain Facade maximum solar irradiation. On roofs, the availability of the solar resource is the highest

\begin{tabular}{|c|c|c|}
\hline & & $\begin{array}{l}\text { with } \\
\geq 90 \% \text {. The optimal solar irradiation on roofs } \\
\text { located at the cities }\left(1^{\circ} \leq \varnothing \leq 30^{\circ} \mathrm{S}\right) \text { facing } \\
\text { North. On facades, the availability of the solar } \\
\text { resource is almost always below } 60 \% \text {. The } \\
\text { optimal solar irradiation on facades located the } \\
\text { cities }\left(15^{\circ} \leq \varnothing \leq 30^{\circ} \mathrm{S}\right) \text { facing North and the } \\
\text { cities }\left(1^{\circ} \leq \varnothing \leq 10^{\circ} \mathrm{S}\right) \text { facing East/West [11]. }\end{array}$ \\
\hline Singapore & Roof & $\begin{array}{l}\text { The effect of orientation for low- slope }\left(15^{\circ}\right) \\
\text { modules is negligible. The East oriented } \\
\text { modules produce slightly higher } \\
\text { energy than other orientations. From predicted } \\
\text { annual energy [12]. }\end{array}$ \\
\hline Australia & Roof & $\begin{array}{l}\text { The } 5.5^{\circ} \mathrm{N} / 56 \text { system generates more energy } \\
\text { than the } 2.5^{\circ} \mathrm{S} / 60 \text { system. The theoretically } \\
\text { optimal tilt angle and orientation for PV systems } \\
\text { in Brisbane, Australia will be approximately } 26^{\circ} \\
\mathrm{N} \text { facing true North (Southern Hemisphere) } \\
\text { [13]. }\end{array}$ \\
\hline Greece & Roof & $\begin{array}{l}\text { The deviation of the angle PV pairs } 15^{\circ} \text { (fixed) - } \\
15^{\circ} \text { (variable) is more little than the deviation of } \\
\text { angle PV pairs } 15^{\circ} \text { (fixed) }-0^{\circ} \text { (variable), } 15^{\circ}- \\
30^{\circ} \text { (variable), } 15^{\circ}-45^{\circ} \text { (variable), } 15^{\circ}-75^{\circ} \\
\left(\text { variable), and } 15^{\circ}-60^{\circ} \text { (variable). The angle of }\right. \\
15^{\circ}\left( \pm 2.5^{\circ}\right) \text { is optimum tilt angle for maximum } \\
\text { energy production in entire summer season in } \\
\text { Athens [14]. }\end{array}$ \\
\hline Korea & $\begin{array}{c}\text { Facade } \\
\text { (Model) }\end{array}$ & $\begin{array}{l}\text { The building can harvest the maximum energy } \\
\text { production on mono-crystalline PV panels with } \\
\text { a horizontally inclined angle of } 60^{\circ} \text { and a } \\
\text { vertically inclined angle that is smaller than } 15^{\circ} \text {. } \\
\text { The optimal solution for applying BIPV systems } \\
\text { is a function of facade surface area, the } \\
\text { inclination of panel, module type, installation } \\
\text { distance to module length ratio, and direction } \\
\text { [15]. }\end{array}$ \\
\hline
\end{tabular}

Table 1 above shows Othman \& Rusdhi [7], Cronemberger [11], and Saber [12] agrees that BIPV placement in equatorial areas is more suitable to be installed on roofs with slope angle to produce maximum energy production. Othman \& Rusdhi [7], the roof should be at a slope angle of fewer than 20 degrees to expand and extend the exposure time in all orientations. Cronemberger [11], the availability of solar potential yield on the roofs for the cities in range $\left(1^{\circ} \leq \varnothing \leq 30^{\circ} \mathrm{S}\right)$ facing North. While the availability of solar potential yield on the facades for the cities in range $\left(15^{\circ} \leq \varnothing \leq 30^{\circ} \mathrm{S}\right)$ facing North. Saber et al. (2014), a roof with lower sloping angle causes the orientation has no effect on the production of electrical energy.

From the table 1 above also shows Yan [13], Kaldellis \& Zafirakis [14], and Hwang [15] agrees that BIPV placement in areas far from the equator should face the equator with varying orientation and angle on the roof and wall to produce maximum energy production. Yan [13], the slope angle should be smaller than latitude in Brisbane. Kaldellis \& Zafirakis [14], the slope angle should be smaller than the latitude in Athens during summer. Hwang [15], the maximum energy production is influenced not only by the orientation and the varying angle but also by the horizontalvertical of the panel position and the tilt angle.

In building design, Hachem [16] proves that there is a correlation between orientation variations of typical residential units in site layouts with curved street patterns in expanding roof surfaces and walls for sunlight access, 
which implements the BIPV system. Horizontal observations just because it only changes orientation and distance between buildings on site layout variations.

Based on all explanations above, BIPV placement that improves the performance of energy production is determined by the latitude location and shape of the building against sun exposure. Each region has a difference in the incidence angle so that it affects the length of time exposed and the extent of an area exposed. The region in range $\left(30^{\circ} \mathrm{N} \leq \varnothing \leq 30^{\circ} \mathrm{S}\right)$ has high solar irradiation on the roof facing to equator. The equatorial region $\left(10^{\circ} \mathrm{N} \leq \varnothing \leq\right.$ $10^{\circ} \mathrm{S}$ ) has the highest solar irradiation on the roofs facing any orientation (more than $90 \%$ of the maximum irradiation for an optimally-inclined-oriented surface). So that there are the suitability of the building envelopes for BIPV placement on roofs in this latitude range. While facades have a value of solar irradiation lower than the roof in all regions (below $60 \%$ of the maximum irradiation for an optimally-inclined-oriented surface). The regions far from the equator (out of equator region range) have the highest solar irradiation value on the facades facing the equator, including those facing East-West. So that there are the suitability of the building envelopes for BIPV placement on facades in this latitude range. In the equator region, on the facades facing East-West also has a high solar radiation which can be utilized for BIPV placement due to the low position of the sun during sunrise and sunset.

The shape of the building can be utilized to increase the building surfaces for getting solar potential. The strategy for units at site layout with the variation of orientation, street pattern, and density. The high of annual energy production of units at site layout with a curved pattern has an advantage in spreading peak generation of hourly electrical energy. The variation of orientation able to produce electrical energy with the different time of peak generation spreadly in hours. This can be an economic advantage since the cost and price of electricity often vary according to the time of day. It is a potency that can be explored to increase BIPV application in neighborhood settlement scale.

\section{CONCLUSION}

BIPV is an integral part of the building envelope such as the roof or the facade. Sun's position that producers incidence angle determines the BIPV placement on a building. Incidence angle should fall perpendicularly on a surface to obtain the high of an intensity of solar irradiation. The equatorial region has relatively high of incidence angle throughout the year. Therefore, most of BIPV placement in the equator region are on rooftops with a low slope to produce maximum electrical energy. Roofs are so far considered to be the ideal field for BIPV placement since roofs provide the best energy generation. While BIPV placement in regions far from the equator not only on rooftops but also on facades due to the variation of incidence angles. The farther away from the equator, the BIPV placement on the facades more plays because of the wide of azimuth angle that can be optimized ranging from Northeast to Northwest (Southern hemisphere).

The potency of BIPV can be explored in building design with the variation of orientation and shape to increase the building surfaces for getting solar potential.

\section{REFERENCES}

[1] A. E. F. Taylor, Illumniatiom Fundamentals. Rensselaer Polytechnic Institute, 2000.

[2] J. A. Duffie and W. A. Beckman, Solar engineering of thermal processes. New Jersey: Wiley, 2013.

[3] K. Farkas, F. Frontini, L. Maturi, C. Roecker, A. Scognamiglio, and I. Zanetti, "Solar energy systems in architecture: Integration criteria and guidelines.," 2012.

[4] V. V. Tyagi, N. A. A. Rahim, N. A. Rahim, and J. A. Selvaraj, "Progress in solar PV technology: Research and achievement," Renew. Sustain. Energy Rev., vol. 20, pp. 443-461, Apr. 2013.

[5] S. Roberts and N. Guariento, Building Integrated Photovoltaics: A Handbook. Berlin: SPRINGER VERLAG NY, 2009.

[6] C. Peng, Y. Huang, and Z. Wu, "Building-integrated photovoltaics (BIPV) in architectural design in China,” Energy Build., vol. 43, no. 12, pp. 3592-3598, Dec. 2011.

[7] A. R. Othman and A. T. Rushdi, "Potential of Building Integrated Photovoltaic Application on Roof Top of Residential Development in Shah Alam,” Procedia - Soc. Behav. Sci., vol. 153, pp. 491-500, Oct. 2014.

[8] B. Petter Jelle, C. Breivik, and H. Drolsum Røkenes, "Building integrated photovoltaic products: A state-of-the-art review and future research opportunities," Sol. Energy Mater. Sol. Cells, vol. 100, pp. 69-96, May 2012.

[9] M. Tominaga, "Opportunities for thin film photovoltaics in Building Integrated Photovoltaics (BIPV) with a focus on Australia,” Murdoch University, 2009.

[10] R. L. Knowles, "The solar envelope: its meaning for energy and buildings,” Energy Build., vol. 35, no. 1, pp. 15-25, Jan. 2003.

[11] J. Cronemberger, E. Caamaño-Martín, and S. V. Sánchez, "Assessing the solar irradiation potential for solar photovoltaic applications in buildings at low latitudes - Making the case for Brazil,” Energy Build., vol. 55, pp. 264-272, Dec. 2012.

[12] E. M. Saber, S. E. Lee, S. Manthapuri, W. Yi, and C. Deb, "PV (photovoltaics) performance evaluation and simulation-based energy yield prediction for tropical buildings," Energy, vol. 71, pp. 588-595, Jul. 2014.

[13] R. Yan, T. K. Saha, P. Meredith, and S. Goodwin, "Analysis of yearlong performance of differently tilted photovoltaic systems in Brisbane, Australia," Energy Convers. Manag., vol. 74, pp. 102-108, Oct. 2013.

[14] J. Kaldellis and D. Zafirakis, "Experimental investigation of the optimum photovoltaic panels' tilt angle during the summer period,” Energy, vol. 38, no. 1, pp. 305-314, Feb. 2012.

[15] T. Hwang, S. Kang, and J. T. Kim, "Optimization of the building integrated photovoltaic system in office buildings-Focus on the orientation, inclined angle and installed area,” Energy Build., vol. 46, pp. 92-104, Mar. 2012.

[16] C. Hachem, "Investigation of Design Parameters for Increased Solar Potential of Dwellings and Neighborhoods," Concordia University, 2012. 